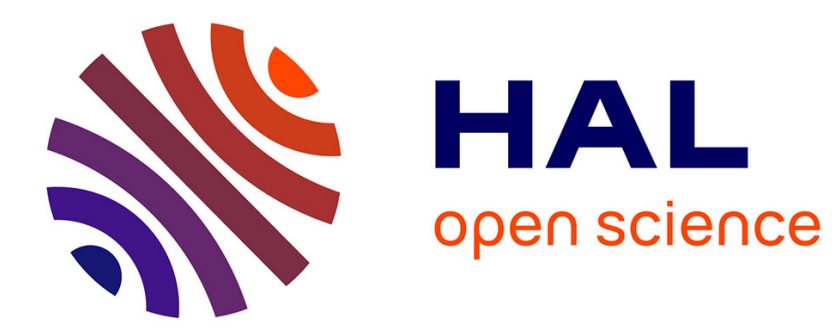

\title{
The Economic Growth Impact of Hurricanes: Evidence from US Coastal counties
}

\author{
Eric Strobl
}

\section{To cite this version:}

Eric Strobl. The Economic Growth Impact of Hurricanes: Evidence from US Coastal counties. 2009. hal-00392382

\section{HAL Id: hal-00392382 \\ https://hal.science/hal-00392382}

Preprint submitted on 7 Jun 2009

HAL is a multi-disciplinary open access archive for the deposit and dissemination of scientific research documents, whether they are published or not. The documents may come from teaching and research institutions in France or abroad, or from public or private research centers.
L'archive ouverte pluridisciplinaire HAL, est destinée au dépôt et à la diffusion de documents scientifiques de niveau recherche, publiés ou non, émanant des établissements d'enseignement et de recherche français ou étrangers, des laboratoires publics ou privés. 


\title{
ECOLE POLYTECHNIQUE
}

CENTRE NATIONAL DE LA RECHERCHE SCIENTIFIQUE

\section{THE ECONOMIC GROWTH IMPACT OF HURRICANES:} EVIDENCE FROM US COASTAL COUNTIES

\author{
Eric STROBL
}

May 2009

Cahier $n^{\circ} \quad 2009-17$

\section{DEPARTEMENT D'ECONOMIE}

Route de Saclay

91128 PALAISEAU CEDEX

(33) 169333033

http://www.enseignement.polytechnique.fr/economie/

mailto:chantal.poujouly@polytechnique.edu 


\title{
The Ec onomic Growth Impact of Huricanes: \\ Evidence from US Coastal Counties*
}

\author{
Eric Strobl** \\ Ecole Polytechnique Paris
}

\begin{abstract}
We estimate for the first time the impact of hurricane strikes on local economic growth rates and how this is reflected in more aggregate growth patterns. To this end we assemble a panel data set of US coastal counties' growth rates and construct a novel hurricane destruction index that is based on a monetary loss equation, local wind speed estimates derived from a physical wind field model, and local exposure characteristics. Our econometric results suggest that in response to a hurricane strike a county's annual economic growth rate will initially fall by 0.8 , but then partially recover by 0.2 percentage points. While the pattern is qualitatively similar at the state level, the net effect over the long term is negligible. Hurricane strikes do not appear to be economically important enough to be reflected in national economic growth rates.
\end{abstract}

May 2009

JEL Classification: 018, Q56

Keywords: hurricanes, economic growth, US coastal counties

* I am grateful for financing from La Chaire Développement Durable of the Ecole Polytechnique.

${ }^{* *}$ Corresponding author: Dept. of Economics, Ecole Polytechnique, 91128 Palaiseau, France.

email: eric.strobl@polytechnique.edu 


\section{Introduction}

Given the potential havoc and destruction caused by hurricanes, the common fascination with these generally unpredictable events is not surprising. For instance, the unfolding destruction of Hurricane Katrina in 2005, estimated by Pielke et al (2008) to have caused over 80 US billion dollars in damages in Lousiana and Missippi alone, was followed on television by millions worldwide. Worryingly in this regard is that there appears to be an increasing trend in the number and strength of hurricanes over the last decadel, which some argue is linked to global warming. ${ }^{2}$ Moreover, the regions directly affected, i.e., coastal areas, are, at least in the US, those where a large and growing part of total economic activity is located and hence the regions that are also driving a substantial portion of national economic growth. ${ }^{3}$ Thus, accurately assessing how economies are likely to be affected by striking hurricanes, both at the local and at the national level, is arguably of considerable importance to policymakers and academics alike.

The primary negative impact of hurricanes on affected regions involves the (permanent) destruction of property in terms of housing, capital stock, and agricultural crops, where losses in these factors may additionally lead to a (temporary) disruption in production in many industries. ${ }^{4}$ However, at the same

\footnotetext{
1 Webster et al (2005).

2 See, for example, Emanuel (2005), Nordhaus (2006), and Elsner (2007).

3 Rappaport and Sachs (2003).

${ }_{4}^{4}$ Although there may be some losses in life, these tend nowadays at least in the US to be negligible.
} 
time the subsequent receipt of disaster assistance, clean-up and recovery activity, and the production of replacement capital will serve to act as a counterweight to any losses. ${ }^{5}$ Additionally some of the losses may be insured and payments in this regard may be coming from outside the affected region. Uncertainty regarding the exact interplay and relative size of these factors means that the net economic effect of hurricane strikes is not at all obvious. Moreover, even if the losses largely outweigh the boosts to local economic growth from recovery activity, it is not clear to what extent this may be reflected in more aggregate growth patterns, since hurricanes, as most natural disasters, tend to be very localized phenomina relevant only for particular regions. ${ }^{6}$

Surprisingly, however, as of date there is to the best of our knowledge no comprehensive study, for the US or elsewhere, of how hurricane strikes may have affected local growth patterns and how any local impact translates into more aggregate levels of economic growth. ${ }^{7}$ More precisely, while there are a few papers that have examined the local impact of hurricanes, these have either focused on particular types of micro-level responses or dealt with the impact on the local labour market. For instance, Evans et al (2008) discover that fertility rates in the US Atlantic and Gulf of Mexico region change in response to

\footnotetext{
5 See Horwich (2000) for a discussion of this.

6 As a matter of fact, in a study of the Kobe earthquake in Japan, which was the most severe earthquake in modern times to strike an urban area, Horwich (2005) looking at GDP patterns over the period argues that there were no observable macroeconomic effects.

7 One may want to note, for instance, that even in the US there is no official systematic data collection on the impact of natural disasters and that while standard source data for GDP and income incorporate the effect they do not separately identify it. See http://www.bea.gov/katrina/index2.htm.
} 
hurricanes. Also, Belasen and Polacheck (2008) show that employment in Florida employment fell in response to hurricanes by between 1.5 and 5 per cent. From a macro-economic perspective there are, in contrast, a handful of papers that provide estimates of the growth impact of hurricane strikes. For instance, Bluedorn (2005) studies the response of the current account to hurricane activity in the Central American and Caribbean region and his findings suggest that the median damaging hurricane will cause output to fall by 0.3 percentage points, while Strobl's (2008) study of the same region suggests that economic growth rates are reduced by 0.8 percentage points for an average destructive hurricane. However, it is not clear whether such results from developing county samples are very relevant for a industrialized economy like the US, given that it appears to be a stylized fact in the literature that economic losses due to natural disasters are negatively correlated with economic wealth. ${ }^{8}$

In this paper we thus explicitly set out to estimate the net growth impact of hurricanes on affected local economies, as well as to what extent such effects spill over into more aggregate economic growth patterns. To this end we develop a hurricane destruction index that is based on a monetary loss equation, local wind speed estimates derived from a physical wind field model, and local exposure characteristics and estimate its impact on the growth rates of a panel of counties in the relevant US coastal area. Our econometric results suggest that in response to a hurricane strike a county's annual economic

8 See, for instance, Kahn (2005) and Toya and Skidmore (2007). 
growth rate will initially fall by 0.8 , but then partially recover by 0.2 percentage points. This is arguably a relative large impact given that the average annual county level growth rate is around 1.68 per cent. While the pattern is qualitatively similar at the state level, the overall the net long term effect is negligible. Hurricane strikes do not appear to be economically important enough to be reflected in national economic growth rates.

The remainder of the paper is organized as follows. In the following section we describe the nature of hurricanes and their destruction potential. Section III introduces our hurricane destruction proxy. In Section IV we describe our data. The econometric analysis is contained in Section $\vee$. Finally, concluding remarks are given in the final section.

\section{Some Basic Facts about Humicanes and their Destructive Power}

A tropical cyclone is a meteorological term for a storm system, characterized by a low pressure system center and thunderstorms that produce strong wind and flooding rain, which generally first forms, and hence its name, in tropical regions of the globe. 9 Depending on their location and strength, tropical cyclones are referred to by various other names, such as hurricane, typhoon, tropical storm, cyclonic storm, and tropical depression. Tropical storms in the North Atlantic Basin, as we study here, are termed hurricanes if they are of

\footnotetext{
9 The term "cyclone" derives from the cyclonic nature of such storms, with counterclockwise rotation in the Northern Hemisphere and clockwise rotation in the Southern Hemisphere.
} 
sufficient strength. 10 Their season can start as early as the end of May and last until the end of November, although it generally takes place between July and October.

We depict a radar composite picture of Hurricane Andrew, which made landfall in Florida on August 24 in 1992, as a typical example of a hurricane in Figure 1. As can be seen, in terms of its structure, a hurricane will generally harbor an area of sinking air at the center of circulation, known as the 'eye, where weather in the eye is normally calm and free of clouds, though, if over the ocean, the sea under the eye may be extremely violent. ${ }^{11}$ Outside of the eye curved bands of clouds and thunderstorms move away from the eye wall in a spiral fashion, where these bands are capable of producing heavy bursts of rain, wind, and tornadoes. One may want to take note that a hurricane appears to affect a large area surrounding its eye and that its structure is not symmetric. As a matter of fact, hurricane strength tropical cyclones are generally about $500 \mathrm{~km}$ wide, although they can vary considerably. Hurricanes are for convenience sake typically categorized in terms of their wind speed on the Saffir-Simpson Scale, where the scale ranges from 1 to 512, although Category 5 hurricanes are fairly rare in the North Atlantic Basin. ${ }^{13}$ One may also

\footnotetext{
10 Generally at least $119 \mathrm{~km} / \mathrm{hr}$. In order to be considered a tropical storm the storm must have maximum wind speed of at least $55 \mathrm{~km} / \mathrm{hr}$. To be upgraded to a hurricane these speeds must reach at least $119 \mathrm{~km} / \mathrm{hr}$.

11 National Weather Service (October 19, 2005). Tropical Cyclone Structure. JetStream - An Online School for Weather. National Oceanic \& Atmospheric Administration.

12 Scale definitions in terms of miles per hour: (1) 119-153, (2) 154-177, (3) 178-209, (4) 210-249, and (5) 250+;

13 Willoughby and Black (1995).
} 
want to note that hurricanes generally lose their strength quickly as they move over land due to land friction and the lack of moisture and heat that the ocean would provide. ${ }^{14}$

Physical damages due to hurricanes typically take a number of forms. Firstly, the strong winds associated with the storm may cause considerable structural damage to buildings as well as crops. Secondly, there is generally strong rainfall associated with a hurricane, which can result in extensive flooding and, in sloped areas, landslides. Finally, the high winds pushing on the ocean's surface can cause the water near the coast to pile up higher than the ordinary sea level, and this effect combined with the low pressure at the center of the weather system and the bathymetry of the body of water results in storm surges. Generally these surges are the most damaging aspect of hurricanes. In particular, storm surges can cause severe property damage, as well as destruction and salt contamination of agricultural areas. ${ }^{15}$ Such flooding may extend up to $40 \mathrm{~km}$ or more from the coast for maximum strength storms.

\section{A Humicane Destruction Proxy}

Previous studies of the local impact of hurricane destruction have resorted to using simple measures of hurricane incidence or their maximum observed Saffir-Simpson scale category as the hurricane eye passes directly over locations

\footnotetext{
14 See NOAA at http://www.aoml.noaa.gov/hrd/tcfaq/C2.html.

15 Yang (2007).
} 
as a proxy of their local destruction. ${ }^{16}$ As outlined earlier, in reality hurricanes may have a destructive impact on spatially potentially very large areas, and not just where the eye directly passes over. Moreover, the extent of this destruction is unlikely to be uniform across localities, but will depend on the position relative to the eye, the maximum wind speed, and local characteristics, amongst other things.

In order to take account of the complex nature of hurricanes we thus here, in contrast to the previous literature, avail of a proxy of local wind speed experienced that is derived from a model of the spatial structure and movement of hurricanes, and hence of wind speeds experienced directly along the track as well as locations around it. We then translate these local wind speeds into a proxy of local destruction. More precisely, as noted by Emanuel (2005), both the monetary losses in hurricanes as well as the power dissipation of these storms tend to rise roughly to the cubic power of maximum observed wind speed. ${ }^{17}$ Consequently, he proposes a simplified power dissipation index that can serve to measure the potential destructiveness of hurricanes as ${ }^{18}$ :

$\mathrm{PDI}=\int_{0}^{\tau} V^{3} d t$

16 See, for instance, Belasen and Polacheck (2007).

17

18 This index is a simplified version of the power dissipation equation $P D=2 \pi \int_{0}^{t} \int_{0}^{r_{0}} C_{D \rho}|V|^{3} r d d t$ where the surface drag $\left(C_{D}\right)$, surface air density $(\rho)$, and the radius of the storm (ro) are taken as given since these are generally not provided in historical track data. Emanuel (2005) notes that assuming a fixed radius of a storm is likely to introduce only random errors in the estimation. He similarly argues that surface air density varies over roughly $15 \%$, while the surface drag coefficient levels off at wind speeds in excess of $30 \mathrm{~m} / \mathrm{s}$, so that assuming that their values are fixed is not unreasonable. 
where $V$ is the maximum sustained wind speed, and $\tau$ is the lifetime of the storm as accumulated over time intervals t. Here we modify this index to obtain a proxy of damages due to hurricanes at the county level i using census tract level j data. More precisely, the total destruction due to the $r=1, \ldots . . k$ storms that affected county $i$ at time $t$ is assumed to be :

$\operatorname{HURR}_{i, t}=\sum_{j=1}^{m} \sum_{r=1}^{k} \bar{V}_{i, j, r, t}^{3} w_{i, j, t}$

where $\bar{V}$ is an estimate of the wind speed due to storm $r$ observed in census tract $\mathrm{j}$ at time $\mathrm{t}$, to be described in detail in Section III. The w's are weights assigned according to characteristics of the affected census tracks intended to capture geographical differences within counties in terms of the potential exposure if a hurricane were to strike. In this regard, we use the time varying share of population of each individual census tract in its county at $t-1$, where the underlying argument is that of two equally affected (in terms of wind speed) areas the one where more people live is likely to be more important in terms of adding to county level damage incurred. ${ }^{19}$

Finally, one should note that Nordhaus (2006) argues that the relationship of costs and wind speed is in fact not to the cubic, found by Emanuel (2005), but rather to the eighth power. More specifically, he regresses the log of the cost per hurricane normalized by US GDP on the logged maximum wind speed for a

\footnotetext{
19 While when first delineated census tracts are designed to be homogeneous with respect to population characteristics, economic status, and living conditions, population size tends to change over time, particularly for coastal counties. The census tracts' population size in our sample of coastal counties varies between around 2,500 and 8,000 inhabitants.
} 
set of $20^{\text {th }}$ century hurricanes and finds a coefficient of 7.6 on the wind speed. However, further investigation using his data demonstrates that this result is sensitive to the measure of cost he uses. In particular, arguably US GDP is unlikely to be a good normalization for costs, since hurricanes typically only affect areas close to the coast and not all of the US. Moreover, the relative local wealth that was affected is likely to have changed substantially over the period as coastal communities have grown in size and income. ${ }^{20}$ When one instead regresses the log of the normalized cost values calculated by Pielke et al (2005) - who normalize damages with regard to changes in inflation, population, and wealth of affected counties only - on the log of maximum observed wind speeds of the hurricanes in Nordhaus' data set, one finds that the resultant coefficient implies that costs rise instead to about the $3.6^{\text {th }}$ power of wind speed, and thus much more in line with Emmanuel (2005) and supportive of the proxy that we use in (2).

\section{Data}

\subsection{Geographic Area of Study}

Normally only a small proportion of total geographic area of the US, namely that relatively close to the coast, is affected by hurricanes since these quickly lose speed once they become landfall. Moreover, as outlined earlier, storm surges generally cause most of the damages due to hurricanes, and this

20 See Rappaport and Sachs (2003). 
again is most relevant for coastal areas. We thus specifically focus our analysis on the US coastal counties in the North Atlantic Basin region. In terms of identifying coastal counties in this region we rely on the list generated by the Strategic Environmental Assessments Division of the National Oceanic and Atmospheric Administration (NOAA). Accordingly, coastal counties are defined as those which have at least 15 per cent of their land in the coastal watershed ${ }^{21}$ or that comprise at least 15 per cent of a coastal cataloging unit22. Within the hurricane relevant North Atlantic Basin region this constitutes a total of 409 coastal counties located over 19 states. We show these, in grey colour, in Figure 2.

\subsection{Economic Growth Data}

To construct proxies of county level per capita economic growth rates and per capita wealth we resort to the Bureau of Economic Analysis' (BEA) Local Area Personal per Capita Income county level estimates available since 1969. Personal income in the BEA data is defined as the income received by all persons from all sources and constitutes the sum of net earnings by place of residence, rental income of persons, personal dividend income, personal interest income, and personal current transfer receipts. We convert these nominal values to constant 2005 dollars using the US consumer price index. As can be seen from the summary statistics in Table 1, the average annual county

\footnotetext{
${ }^{21}$ A coastal watershed is composed of all lands within Esturaine Drainage Areas (EDA) or Coastal Drainage Areas (CDA) in the NOAA's Coastal Assessment Framework.

22 A coastal cataloging unit is a drainage basin that falls entirely within or straddles an EDA or CDA.
} 
growth rate over the 1975 to 2005 period was 1.68. However, the high standard deviation relative to this mean indicates that it varies substantially over time and across space within our coastal community sample.

One should note that the BEA specifically discusses how natural disasters are likely to be accounted for in their personal income estimates. ${ }^{23}$ In particular they argue that natural disasters generally will have two major effects on the data. Firstly, there will be destruction of property, where property losses net of the associated insurance claims will be incorporated as one-time effects. ${ }^{24}$ In this regard, damage to property of household enterprises will reduce proprietors' income and rental income by the amount of uninsured losses, measured by consumption of fixed capital less of business transfers. Damage to consumer goods, on the other hand, will affect personal current transfer receipts net of the amount of insured losses of these goods. The second effect of natural disasters is likely to be a disruption of the flow of income in the economy as normal economic activity is interrupted. This will generally be embedded within the data on which the personal income estimates are based. For example, many industries in the directly affected area will experience a reduction in earnings as production is interrupted, while for others there may be an increase. Typically, however, these income flows are reduced in the short-term (e.g., a reduction in

\footnotetext{
$23 \mathrm{http} / / /$ www.bea.gov/katrina/index2.htm

${ }^{24}$ For example, the BEA estimated that Hurricanes Katrina, Rita, and Wilma reduced nonfarm proprietors' income and rental income of persons net of business current transfer payments in Lovisiana by 18,243 millions of dollars in 2005.
} 
consumer spending) and are boosted later (e.g., an increase in construction activity).

\subsection{Population Data}

In order to make (2) operational we need data on both local wind speeds as well as population shares. Our census tract level population shares, i.e., the w's, are derived from the decennial population census 1970, 1980, 1990, and 2000, where the calculated shares were linearly interpolated to estimate annual values between these years for each census tract. As can be seen from Table 1 the average census tract has nearly 5 per cent of total county level population, albeit with considerable variation.

\subsection{Huric a ne Data}

Since historical data on hurricanes normally only provide wind speeds at locations where the eye passes over, one needs to simulate these for areas surrounding the eye. The use of mathematical simulation methods to estimate local hurricane wind speeds was first introduced by Russel (1968) and a large number of studies have since followed his proposed methodology. ${ }^{25}$ The basic approach in all of these studies has essentially been to take site specific statistics of key hurricane parameters, including the radius to maximum wind speed, heading, translation speed, and the coast crossing position or distance to closest approach, implement a Monte Carlo simulation to sample from each distribution, use a mathematical representation of a hurricane along a straight

25 See, for instance, Batts et al (1980), Georgiou (1985) and Vickery and Twisdale (1995). 
path that satisfies the sampled path, and then record the simulated wind speeds. Here we use wind speed data generated from a new wind field model that is arguably superior to previous methods 26 , and now provides the underlying data for hurricane loss modeling in the well known HAZUS software. ${ }^{27}$ In this model the full track of a hurricane is modeled, beginning with its initiation over the ocean and ending with its final dissipation. In essence it consists of two main components: (1) a mean flow wind model that describes upper level winds and (2) a boundary layer model that allows one to estimate wind speeds at the surface of the earth over a set of rectangular nested grids given the estimated upper level wind speeds. The mean flow model underlying the HAZUS data is that developed by Vickery et al (2000), which solves the full nonlinear equations of motion of a translating hurricane then parameterizes these for use in simulations. One should note that compared to previous approaches this allows for a more accurate characterization of asymmetries in fast-moving hurricanes. The boundary layer model used is that of Vickery et al (2008) which is based on a combination of velocity profiles computed using dropsond data and a linear hurricane boundary layer model. Its advantage, compared to earlier methods, lies in producing better estimates of the effect of the sea-land interface in reducing wind speeds and a more realistic representation of the wind speeds near the surface and for better. Extensive verification through comparison with

\footnotetext{
26 See FEMA (2007).

27 HAZUS is a GIS-based natural hazard loss estimation software package developed and freely distributed by FEMA.
} 
real hurricane wind speed data showed that this new wind speed model provided a good presentation of hurricane wind fields. ${ }^{28}$ In its most recent release of HAZUS (version MR3), the above methodology was implemented to generate maximum wind speeds, if these were at least 50 miles per hour, at the census tract level using historical hurricane tracks of tropical storm that were at least of category 3 at the time of US landfall over 1900 through 2005 as given in the HURDAT database.29, 30

We first depict all tropical storm activity in the North Atlantic Basin close to the US coast over the 1970-2005 period as contained in the HURDAT database, even if these did not make the HAZUS cut-off criteria, in Figure 3 - where the red portion of the lines indicates speeds of at least hurricane strength. As can be seen, while many storms transverse the basin, only a small portion make landfall on the US coast.

For our benchmark period, 1970-2005, 21 hurricanes in the HURDAT database made the HAZUS cut-off criteria, and hence for which we have local wind field estimates, and we list these in Table 2. We also depict their tracks in Figure 4 and two points are noteworthy in this regard. Firstly, various counties along the whole coastline were affected, although especially in Florida, Alabama, Mississippi, Louisiana, and Texas. Secondly, most hurricanes lose wind

\footnotetext{
28 FEMA (2007).

29 We would like to thank Frank Lavelle for provision of the data.

30 The HURDAT database consists of six-hourly positions and corresponding intensity estimates in terms of maximum wind speed of tropical cyclones in the North Atlantic Basin over the period 1851-2006 and is the most complete and reliable source of North Atlantic hurricanes; see Elsner and Jagger (2004).
} 
speeds fairly quickly to be considered hurricanes or even tropical storms once they leave the coastal area.

\subsection{The Huric a ne Destruction Proxy}

To demonstrate the role of the individual components, i.e., $\bar{V}$ and $w$, in our hurricane damage proxy, HURR, we resort again to the Hurricane Andrew example shown in Figure 1. It first made landfall in Miami-Dade County in Florida on the $24^{\text {th }}$ of August 1992 and then later crossed into southwest Louisiana. One shold note that it is considered the second-most-destructive hurricane in U.S. history ${ }^{31}$, and the last of three Category 5 hurricanes that made U.S. landfall during the 20th century. ${ }^{32}$ Wind speeds during landfall reached over 115 miles per hour and storm surges were as high as 5.2 meters in Southern Florida. In terms of damage, Andrew caused around $\$ 26.5$ billion worth $1 \$ 38.1$ billion in 2006 US dollars), with most of that damage cost in south Florida.

Hurricane Andrew's complete track as taken from HURDAT is shown in Figure 5, where again the red portion of the line indicates when the storm was of hurricane intensity. As can be seen, Andrew maintained hurricane strengths even as it made a second landfall in Louisiana, but then was reclassified as a tropical storm once it left the state. The wind speeds generated from the HAZUS wind field model for Florida by census tract along with the actual hurricane tract (the dotted black line) are shown in Figure 6, where darker shading indicates stronger wind speed. Accordingly, these correspond fairly well to what one

\footnotetext{
${ }^{31}$ It was the most destructive hurricane until the arrival of Katrina in 2005.

32 Landsea et al (2004).
} 
would expect from the radar composite image of the hurricane given in Figure 1. The highest wind speeds were experienced along the track of the hurricane 33 , but even census tracts over $180 \mathrm{~km}^{34}$ away from the actual track of the hurricane eye were subject to potential damage through wind.

In terms of assessing how the local exposure to potential damages may vary by census tract with regard to its county level importance, i.e., the w's, we depict the census tract level population share (of a county) in Figure 7, where darker shading again indicates higher values. One should in particular note that these weight components are not evenly distributed across Southern Florida census tracts within counties. More specifically, it is clear that census tracts on the west coast tend to have a greater share of a county's population than those on the east. This is in part of course due to fact that there are fewer census tracts within counties in the former area.

The derived coastal values of HURR for Andrew using our proxies $\bar{V}$ and w in (2) are depicted in Figure 8, where darker shading indicates higher values. Again it is obvious that while most of the damage is found along the hurricane's path, other counties both neighboring and further away were also affected. More precisely, in Florida essentially all of the southern tip was affected, while in Luisiana large parts of the state was subject to damaging wind speeds.

\footnotetext{
33 The highest wind speed was calculated to be in Dade county, measuring around 157 miles per hour.

34 For example, census tracts within Broward County at the time of landfall experienced up to 92 miles per hour.
} 
Additionally, a small part of Mississippi was affected when Andrew first entered the state.

Finally, we show the mean value of HURR for all coastal counties over the sample period 1970 to 2005. Accordingly, almost all counties were affected at least once since the 1970s. Most destruction was, unsurprisingly given Figure 9, suffered in Florida, Alabama, Mississippi, Lovisiana, and Texas.

\section{Ec onometric Estimation and Results}

\subsection{Ec onometric Specific ation}

Our first econometric task is to investigate the economic growth impact of hurricane strikes at the county level using our index of destruction. To do so we specify the following simple conditional convergence growth equation: ${ }^{35}$

$\mathrm{GROWTH}_{\mathrm{i}, \mathrm{t}-1 \rightarrow \mathrm{t}}=\alpha+\beta_{1} \log \left(\mathrm{INITIALi,t-1}_{1}\right)+\beta_{2} \mathrm{HURR}_{\mathrm{i}, \mathrm{t}}+\varepsilon_{\mathrm{i}, \mathrm{t}}$

where GROWTH is the per capita economic growth rate in county i over t- 1 to $\mathrm{t}$, INTIAL is the initial wealth per capita in county $i$ at time $t-1$, HURR is our county level destruction proxy, summed over all hurricanes $r$ and all census tracts within counties i at time t, and $\varepsilon$ is an error term.

One should note that with the inclusion of the initial level of wealth per capita term one could easily rewrite (3) to be a dynamic panel model with the lagged dependent variable as one of the regressors. However, it is well known that in many cases dynamic panel regressions are characterized by a

\footnotetext{
35 Noy (2007) uses a similar set-up investigating the macroeconomic consequences of natural
} disasters affect using cross-country cost data from the EM-DAT database. 
systematic bias in the estimator of the coefficient on the lagged dependent variable, as first identified by Nickell (1981). Furthermore, this potential bias in the convergence term may lead to a bias in other coefficients in the model. Thus standard panel estimator such as the Least Squares Dummy Variable (LSDV) or fixed effects would be inappropriate. In order to correct for the bias we hence employ Bruno's (2005) bias corrected LSDV estimator36, which extends the original estimator by Kiviet (1995). ${ }^{37}$ Standard errors on the coefficients are generated via bootstrapping methods, as suggested by Kiviet and Bun (2001).38

One worry with (3) is that there may be spatial dependence between counties' growth rates that are geographically near. To address this with US county data Rappaport and Sachs (2003) and Higgins et al (2006) use Conley's (1999) correction to obtain standard errors that are robust to such spatial correlation. Given that the econometric estimator we use necessitates standard errors to be bootstrapped, we instead explicitly model the spatial dependence

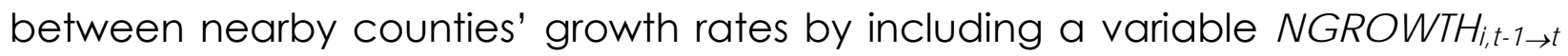

\footnotetext{
36 As initial estimates of the coefficients we use those produced by the Anderson and Hsiao (1982) estimator.

37 Another option would be to use the now standard GMM estimator, such as that proposed by Arellano and Bond (1991), or some IV estimator such as Anderson and Hsiao (1982). However, as shown by Judson and Owen (1999), the corrected LSDV estimator is more efficient and performs better in a panel where the number of individual units is not particularly large and the time dimension not short, as we have here.

38 While Kiviet and Bun (2001) derive an analytical expression for the asymptotic vairancecovariance matrix of the bias corrected LSDV estimator, Monte Carlo simulations suggested that it performed poorly, and hence the authors suggest using a parametric boostrap estimator which takes account of the autoregressive nature of the data generating process (DGP) by bootstrapping from each panel unit. We employ this boostrapping technique here with our county level data. One worry in our context in this regard may also be spatial dependence of the DGP. As a 'rough' way of taking account of this we experimented with bootstrapping from each state group of coastal counties. This made, however, little difference to the estimated standard errors.
} 
capturing the average per capita economic growth rate over t-1 to $t$ in nearby coastal counties.39 More precisely, we follow Higgens et al (2007) and assume that there is a cut-of distance of $200 \mathrm{~km}$, after which two counties' growth rates are independent of each other. To arrive at an average value for those that fall within the cut-off distance we impose a declining weight structure $g\left(d_{i j}\right)=$ $1\left(d_{i j} / 200\right)$, where $d_{i j}$ is the distance between the centers of counties $i$ and $j$. We then identify all nearby counties surrounding county $i$ that fall within this cut-off distance, multiply their GROWTH values by $\mathrm{g}$ and take the mean of this product as NG ROWTH.

\subsection{Ec onometric Results}

Overall our combined data provides us with a balanced panel of 409 counties over the period 1970-2005. The results of estimating (3) on this data first with only including INITAL are shown in the first column of Table 3. The negative and significant coefficient on INITAL suggests a conditional convergence rate of about 15 per cent. Including the neighboring counties' growth rates, i.e., NGROWTH, we find that a country's growth path moves positively with that of neighboring counties in our sample. Moreover, inclusion of this variable reduces the estimated coefficient on INITIAL to 0.13. One may want to note that the implied convergence parameter is not too out of line with recent studies using

\footnotetext{
39 Higgins et al (2007) in their study of growth in US counties use Conley's (1999) correction to obtain standard errors that are robust to such spatial correlation. Given that the econometric estimator we use, outlined subsequently, necessitates standard errors to be bootstrapped we instead use explicitly model the spatial dependence between nearby counties by including GROWTH_nb.
} 
county level data. More specifically, using a cross-sectional variant of Evans (1997) 3SLS approach Higgins et al (2006) find for data for all US counties an average annual convergence rate of between 6-8 per cent over the 1970 to 1998 period, but that this is substantially higher for Southern regions and metropolitan areas, which of course constitute large portions of our coastal county sample.

We next included our hurricane destruction index, HURR. As can be seen from the third column, the resultant coefficient is negative and significant, indicating that a hurricane strike will cause a county's growth rate to fall. Using the estimated coefficient and the mean annual value of destruction due to a hurricane shock (i.e., the mean of non-zero values), our results suggest that in a year in which a county is struck by at least one hurricane, its growth rate will fall on average by 0.79 percentage points. A 'hurricane' year in which destruction was about a standard deviation above the mean would reduce the growth rate by 1.51 percentage points, while the most destruction viewed in any year in any county in our sample ${ }^{40}$ would cause the growth in per capita wealth to fall by at least 5.64 percentage points. One should note that these effect are, given that the average county growth rate lies around 1.68 per cent, arguably relatively large.

As noted earlier, we focus here on coastal counties because these are most likely to be affected by hurricanes and are those for which the damage

40 The county that experienced the highest value of HURR in our sample was Miami-Dade county in Florida in 1992 when Hurricane Andrew struck. 
suffered is likely to be greatest. To examine whether the exclusion of the areas outside our sample for which the HAZUS model produced positive wind field estimates is appropriate, we re-run our specification on the excluded sample of all other non-coastal counties that experienced at least one positive wind speed value during our sample period. As shown in the fourth column, rerunning (3) on this non-coastal sample suggests no significant effects of hurricane strikes on economic growth.

An important component of our destruction proxy is the weighting scheme which is intended to take account of differences in tract level potential destruction, here necessarily estimated by the distribution of population within a county. We thus also investigated whether not controlling for these differences would change our estimate of the growth impact by re-calculating HURR but using an unweighted average of wind speed in (2) in the fifth column of Table 3. One should note that this gives equal weight to maximum wind experienced across census tracts regardless of population differences. Moreover, it does not allow for counties to change their importance in terms of potential destruction exposure over time. The use of this alternative proxy, as shown in fourth column, produces a slightly larger negative effect of a hurricane strike. More specifically, the estimated coefficient and non-zero mean of this index would imply an average effect of 0.87 percentage points.

We also investigated whether there are more long term effects of hurricanes on county level growth rates by including up to t-5 lagged levels of 
HURR. The results of this, shown in column 6, suggest, that in the year immediately after the strike there will be a significant positive effect on a coastal county's growth rate, but no significant impact thereafter. More specifically, evaluated at the mean of a strike this 'recovery' effect is about 0.22 percentage points. Nevertheless, given the immediate negative effect, overall over the long term a hurricane is estimated to reduce economic growth by 0.65 percentage points. In this regard a simple t-test of the hypothesis that the sum of all (significant) coefficients is zero can be decisively rejected.

It is also of interest to examine how the net negative growth impact of hurricanes in coastal counties translate into state level growth patterns, given that a large portion of counties within a state may only be indirectly affected. Additionally, moving to the state level allows us to investigate the effect of hurricanes at quarterly rather than annual frequency. Our destruction index in (2) can of course be easily altered to derive state level measures by using instead the census tract share of state level population as weights. ${ }^{41}$ Given that we found that the effect at the county level lasted up to a year after the strike we include the contemporaneous value as well as up to 7 quarterly lags of the proxy in a state level version of (3). Additionally, in order to again control for spatial dependence we included the average growth rate of neighboring counties as an explanatory variable. The results of this for our 19 coastal county states are given in the first column of Table 4. As with the county level annual

\footnotetext{
${ }^{41}$ We linearilly interpolated our annual tract level population figures to obtain quarterly values.
} 
data there is an immediate negative effect of a hurricane strike, where the estimated coefficient implies a 4.96 percentage point reduction in state level economic growth rates during the quarter in which the hurricane strikes. The positive recovery effect kicks in both in the quarter immediately after state is hit by a hurricane as well as within five quarters of a strike. The former is, however, substantially larger than the latter, increasing economic activity by 4.66 relative to 0.63 percentage points. While this overall implies that the net effect results in an increase of 0.33 percentage points, a simple t-test of the hypothesis that the sum of the coefficients are equal to zero cannot be rejected. Hence there appears to be no significant longer term effect of hurricanes at the state level.

Another advantage of using state level quarterly data is that it extends as far back as 1948 so that we can investigate whether our results are robust over the historical long term. One difficulty in this regard is, however, that tract level population information is not available prior to 1970, so that we cannot weight tract level hurricane wind estimates by local population size. As shown earlier, at the county level using a simple average wind destruction within a county produces a slightly larger negative effect. Moreover, while including further lags of the simple average wind destruction also generates a slightly smaller recover effect, as shown in the last column of Table 3, the long term net growth effect is still slightly larger compared to the one suggested by our population weighted measure. To see how using this alternative, but arguably inferior, measure might affect the estimated impact of hurricane strikes at the state level, we took its 
county level values, multiplied these by county level shares of state level population, and summed this product within states to obtain a state level equivalent measure. Including this proxy in our state level regressions, as shown in the second column of Table 4, confirms the slight differences compared to our tract level measure at the county level. More specifically, the overall net negative effect is larger than for our population weighted measure, suggesting a slight reduction rather than increase in state level economic growth over time. Moreover, there is no additionally recovery effect at the t-5 quarter, but rather the positive effect extends from t-1 to t-2 quarters. Again, however, this additional recovery effect is rather small compared to the one observed at $t-1$. As with the shorter time period, a simple t-test of the hypothesis that the sum of the (significant) coefficients on the hurricane variables is equal to zero cannot be rejected.

We next calculated the effect of hurricane strikes since 1948 with our quarterly state level non-locally weighted proxy. This qualitatively confirms our result for the 1970 to 2005 period where we found a large negative, followed by a large positive and then a smaller recovery effect. However, the estimated coefficients from this longer sample suggest, in contrast, an overall positive effect on state level growth rates of about 0.23 percentage points, where again a t-test suggests that this overall net effect was not statistically significant.

Thus far we have discovered large net negative effects at the county level, and while we found that there was both a negative and recovery effect 
at the state level, the net impact of these over the longer run was negligible. The final task is then to examine whether local natural disasters like hurricanes are economically important enough to make a significant (net) impact on the national economic growth path. Again our destruction proxy can easily be altered to arrive at a national measure by using shares of national level population as weights. The results of using the locally unweighted measure of destruction for our shorter time period with quarterly data and standard OLS are shown in the fourth column of Table 4.42, 43 Accordingly, there is no evidence of any (net) impact of hurricanes on US national growth rates. Moreover, extending our sample period back to 1948, depicted in column two, confirms this lack of an impact. We also experimented with using national GDP growth rate and levels data given that GDP will also capture the production value of other goods and services not reflected in personal income. However, as can be seen from the final two columns of Table 4, similar to the personal income data, one finds no effect of hurricane destruction on national growth rates.

\section{Conclusion}

We investigated whether hurricane strikes had any impact on local economic growth rates and whether any effect in this regard is reflected at

\footnotetext{
42 Using a tract level weighted measure produced qualitatively similar results.

43 For completeness sake our national level measures of income and hurricane destruction also includes Hawaii, which was struck by Hurricane Iniki in 1992, we verified that including Hawaii in our state level regressions did not change our results. Similarly subtracting Hawaiin personal income from the national estimate had not qualitative impact.
} 
higher regional levels. To this end we developed a measure of hurricane destruction based on a monetary loss equation, local wind speed estimates derived from a physical wind field model, and local exposure characteristics and employed this proxy within an economic growth framework on annual county level panel data. Our econometric results suggested that hurricanes have a large (0.8 percentage points) immediate negative impact on counties' growth rates, followed by a smaller (0.2 percentage points) recovery effect in the following year.

Results from using state level quarterly data indicated over the longer term there will be also be an initial negative and subsequent recover effect but that their net long term impact is negligible. We find, in contrast, no evidence that national quarterly economic growth patterns are influenced by hurricane strikes in any significant manner. Thus, overall, our findings suggest that while hurricanes may cause large economic losses and disruption to economic activity at the local level, subsequent 'recovery' activity and the fact that hurricanes are generally spatially very limited means that in the long term these have no net impact at the state level and do not show up in national growth volatility at all.

As a final note of caution one should emphasize that our results should not be taken to suggest that at the state or national level hurricanes are not 'bad' for the economy. Naturally, resources used to replace destroyed capital cannot be used elsewhere and hence growth may even at the level of the 
state be less in the much longer run than if the hurricane had not struck. Similarly, funds used to reimburse insurance claims and provide disaster relief assistance, while perhaps not coming directly from the affected state will have to be sourced somewhere, and thus sacrificed from other potentially more nationally growth enhancing uses. 


\section{References}

Anderson, T. and Hsiao, C. (1982). "Formulation and Estimation of Dynamic Models Using Panel Data", J oumal of Ec onometrics, 18, pp. 570-606.

Arelland, M. and Bond, S. (1991). "Some Tests of Specification for Panel Data: Monte Carlo Evidence and an Aplication to Employment Equations", Review of Ec onomic Studies, 58, pp. 277-297.

Belasen, A. and Polacheck, S. (2008a). "How Disasters Affect Local Labor Markets: The Effects of Hurricanes in Florida", Joumal of Human Resources, forthcoming.

Belasen, A. and Polacheck, S. (2008b). "How Hurricanes Affect Employment and Wages in Local Labor Markets", American Economic Review, Papers and Proceedings, forthcoming.

Blvedorn, J.C. (2005). "Hurricanes: Intertemporal Trade and Capital Shocks", Nuffield College Economics Paper 2005-W22.

Bruno, G. (2005). "Approximating the bias of the LSDV estimator for dynamic unbalanced panel data models", Ec onomic s Letters, 87, pp. 361-366.

Conley, T. (1999). "GMM Estimation with Cross Sectional Dependence", J oumal of Ec onometrics, 92, pp. 1-45.

Elsner, J. (2007). "Granger Causality and Atlantic Hurricanes", Tellus, p. 1-10.

Emanuel, K. (2005). "Increasing Destructiveness of Tropical Cyclones over the past 30 Years", Nature, $4^{\text {th }}$ August 2005, pp. 686-688.

Evans, R., Yingyao, H., and Zhong, Z. (2008). "The Fertility Effect of Catastrophe: U.S. Hurricane Births", J oumal of Population Ec onomics, forthcoming.

Federal Emergency Management Agency (FEMA) (2007). Multi-Hazard LosS Methodology - Hurricane Model. Technical Manual, Washington, D.C.

Higgins, M., Levy, D., and Young, A. (2006). "Growth and Convergence Across the US: Evidence from County-Level Data", Review of Economics and Statistics, 88, pp. 671-681.

Horwich, G. (2000). "Economic Lessons of the Kobe Earthquake", Economic Development and Cultural Change, 48, pp. 521-542.

Judson, R. and Owen, A. (1999). "Estimating Dynamic Panel Data Models: A Guide for Macroeconomists", Ec onomic Letters, 65, pp. 9-15. 
Kahn, M. (2005). "The Death Toll from Natural Disasters: The Role of Income, Geography, and Institutions", Review of Economics and Statistic s, 87, pp. 271284.

Kiviet, J. (1995). "On Bias, Inconsistency and Efficiency of Various Estimators in Dynamic Panel Data Models", J oumal of Ec onometrics, 68, pp. 53-78.

Kiviet, J. and Bun, M. (2001). "The Accuracy of Inference in Small Samples of Dynamic Panel Data Models", Tinbergen Institute Discussion Paper TI 2001-006/4.

Nickell, S. (1981). "Biases in Dynamic Models with Fixed Effects", Econometrica, 49, pp. 1417-1426.

Nordhaus, W. (2006). "The Economics of Hurricanes in the United States", mimeo.

Noy, I. (2008). "The Macroeconomic Consequences of Natural Disasters", J oumal of Development Ec onomics, forthcoming.

Pielke, R., Gratz, J., Landsea, C., Collins, D., Saunders, M., and Musulin, R. (2008). "Normalized Hurricane Damage in the United States: 1900-2005", Natural Hazards Review, 9, pp. 29-42.

Rappaport, Jordan and Sachs, Jeffrey D. (2003). The United States as a Coastal Nation. J oumal of Ec onomic Growth, March, 8(1), 5-46.

Strobl, E. (2008). "The Macro-economic Impact of Natural Disasters in Developing Countries: Evidence from Hurricane Strikes in the Central American and Caribbean Region", Chair Developpement Durable Discussion Paper.

Strobl, E. and Walsh, F. (2008). "The Re-Building Effect of Hurricanes: Evidence from Employment in the US Construction Industry", IZA Discussion Paper 3544.

Toya, H. and Skidmore, M. (2007). "Economic Development and the Impact of Natural Disasters", Ec onomic s Letters, 94, pp. 20-25.

Vickery, P., Skerjl, P., Steckley, A., and Twisdale, L. (2000). "Hurricane Wind Field Model for Use in Hurricane Simulations", Joumal of Structural Engineering, 126, pp. 1203-1221.

Vickery, P., Wadhera, D., Powell, M., and Chen, Y. (2008). "A Hurricane Boundary Layer and Wind Field Model for Use in Engineering Applications", Joumal of Applied Meteorology, forthcoming. 
Webster, P., Holland, G., Curry, J., and Chang, H. (2005). "Changes in Tropical Cyclone Number, Duration, and Intensity in a Warming Environment", Science, 309 , p. 1844-1846.

Yang, D. (2007). "Coping with Disaster: The Impact of Hurricanes on International Financial Flows, 1970-2002", Advances in Economic Analysis \& Policy (B.E. Press), forthcoming. 
Table 1: Humicanes in Our Sample

\begin{tabular}{|c|c|c|c|}
\hline Name & Year & Max. Wind Speed & States Affected in Coastal County Sample \\
\hline UNNAMED & 1948 & 137 & $\mathrm{FL}$ \\
\hline UNNAMED & 1949 & 123 & $\mathrm{CT}, \mathrm{DE}, \mathrm{FL}, \mathrm{GA}, \mathrm{ME}, \mathrm{MD}, \mathrm{MA}, \mathrm{NH}, \mathrm{NJ}, \mathrm{NY}, \mathrm{PA}, \mathrm{RI}, \mathrm{SC}, \mathrm{VA}$ \\
\hline EASY & 1950 & 119 & $\mathrm{FL}, \mathrm{GA}$ \\
\hline KING & 1950 & 125 & $\mathrm{FL}$ \\
\hline CAROL & 1954 & 131 & $\mathrm{CT}, \mathrm{ME}, \mathrm{MA}, \mathrm{NH}, \mathrm{NY}, \mathrm{NC}, \mathrm{RI}$ \\
\hline EDNA & 1954 & 127 & $\mathrm{CT}, \mathrm{ME}, \mathrm{MA}, \mathrm{NH}, \mathrm{NY}, \mathrm{NC}, \mathrm{NC}, \mathrm{RI}$ \\
\hline HAZEL & 1954 & 134 & $C T, D E, M D, M A, N J, N Y, N C, P A, S C, V A$ \\
\hline CONNIE & 1955 & 106 & $\mathrm{DE}, \mathrm{MD}, \mathrm{NJ}, \mathrm{NC}, \mathrm{PA}, \mathrm{VA}$ \\
\hline IONE & 1955 & 115 & $\mathrm{NC}, \mathrm{VA}$ \\
\hline AUDREY & 1957 & 127 & $L A, M D, T X, V A$ \\
\hline GRACIE & 1959 & 125 & GA, NC, SC \\
\hline DONNA & 1960 & 144 & $\mathrm{CT}, \mathrm{DE}, \mathrm{FL}, \mathrm{ME}, \mathrm{MD}, \mathrm{MA}, \mathrm{NH}, \mathrm{NJ}, \mathrm{NY}, \mathrm{NC}, \mathrm{PA}, \mathrm{RI}, \mathrm{SC}, \mathrm{VA}$ \\
\hline CARLA & 1961 & 137 & TX \\
\hline DORA & 1964 & 105 & $\mathrm{FL}, \mathrm{GA}$ \\
\hline HILDA & 1964 & 111 & $\mathrm{AL}, \mathrm{FL}, \mathrm{LA}, \mathrm{MS}$, \\
\hline BETSY & 1965 & 151 & $\mathrm{AL}, \mathrm{FL}, \mathrm{LA}, \mathrm{MS}$ \\
\hline BEULAH & 1967 & 133 & TX \\
\hline CAMILLE & 1969 & 161 & $A L, L A, M S$ \\
\hline CELIA & 1970 & 126 & TX \\
\hline CARMEN & 1974 & 126 & LA, TX \\
\hline ELOISE & 1975 & 131 & $\mathrm{AL}, \mathrm{FL}$ \\
\hline FREDERIC & 1979 & 126 & $\mathrm{AL}, \mathrm{FL}, \mathrm{ME}, \mathrm{MA}, \mathrm{MS}, \mathrm{NH}, \mathrm{NY}$ \\
\hline ALLEN & 1980 & 136 & TX \\
\hline ALICIA & 1983 & 105 & LA, TX \\
\hline GLORIA & 1985 & 119 & $\mathrm{CT}, \mathrm{DE}, \mathrm{ME}, \mathrm{MD}, \mathrm{MA}, \mathrm{NH}, \mathrm{NJ}, \mathrm{NY}, \mathrm{NC}, \mathrm{PA}, \mathrm{RI}, \mathrm{VA}$ \\
\hline ELENA & 1985 & 120 & $\mathrm{AL}, \mathrm{FL}, \mathrm{LA}, \mathrm{MS}$ \\
\hline HUGO & 1989 & 136 & NC, SC \\
\hline ANDREW & 1992 & 157 & $\mathrm{FL}, \mathrm{LA}, \mathrm{MS}$ \\
\hline OPAL & 1995 & 100 & $\mathrm{AL}, \mathrm{FL}, \mathrm{GA}$ \\
\hline FRAN & 1996 & 98 & NC, SC, VA \\
\hline BRET & 1999 & 111 & TX \\
\hline JEANNE & 2004 & 109 & $\mathrm{FL}, \mathrm{GA}$ \\
\hline IVAN & 2004 & 109 & $\mathrm{AL}, \mathrm{FL}, \mathrm{LA}, \mathrm{MS}$ \\
\hline FRANCES & 2004 & 105 & $\mathrm{FL}, \mathrm{GA}$ \\
\hline CHARLEY & 2004 & 147 & $\mathrm{FL}$ \\
\hline WILMA & 2005 & 117 & $\mathrm{FL}, \mathrm{SC}, \mathrm{VA}$ \\
\hline RITA & 2005 & 120 & LA, MS, TX \\
\hline KATRINA & 2005 & 135 & $\mathrm{AL}, \mathrm{FL}, \mathrm{LA}, \mathrm{MS}$ \\
\hline DENNIS & 2005 & 114 & $\mathrm{AL}, \mathrm{FL}$ \\
\hline
\end{tabular}


Table 2: Summary Statistics of Main Variables

\begin{tabular}{|c|c|c|c|c|}
\hline Sample \& Period & Variable & Variable Description & Mean & $\begin{array}{c}\text { St } \\
\text { Dev. }\end{array}$ \\
\hline County & "GROWTH & PI/POP growth rate & 0.0168 & 0.0480 \\
\hline $1970-2005$ & INITIAL & $\log (\mathrm{PI} / \mathrm{POP})$ & 9.3342 & 8.1381 \\
\hline \multirow[t]{3}{*}{ Annual } & NGROWTH & $\begin{array}{l}\text { Distance Weight. Nearby Counties' } \\
\text { GROWTH }_{c}\end{array}$ & 0.0170 & 0.0277 \\
\hline & HURR_tp/106 & $\begin{array}{l}\text { Tract L. Pop. Weight. Hurricane } \\
\text { measure }(\neq 0)\end{array}$ & 0.0483 & 0.0460 \\
\hline & HURR_uw/106 & Unweighted Hurricane measure $(\neq 0)$ & 0.0314 & 0.0309 \\
\hline State & GROWTH & PI/POP growth rate & 0.0040 & 0.0327 \\
\hline 1970-2005 & INITIAL & $\log (\mathrm{Pl} / \mathrm{POP})$ & 10.168 & 0.2521 \\
\hline \multirow[t]{3}{*}{ Quarterly } & NGROWTH & Pop. Weight. Neigbor States' GROWTH & 0.0015 & 0.0120 \\
\hline & HURR_tp/106 & $\begin{array}{l}\text { Tract L. Pop. Weight. Hurricane } \\
\text { measure }(\neq 0)\end{array}$ & 0.0124 & 0.0152 \\
\hline & HURR_cp/106 & $\begin{array}{l}\text { County L. Pop. Weight. Hurricane } \\
\text { measure }(\neq 0)\end{array}$ & 0.0027 & 0.0066 \\
\hline $\begin{array}{l}\text { Tract, 1970-2005, } \\
\text { Annual }\end{array}$ & w & Tract L. Pop. Share of County & 0.048 & 0.101 \\
\hline
\end{tabular}


Table 3: County Level Growth Regressions

\begin{tabular}{|c|c|c|c|c|c|c|c|}
\hline & (1) & (2) & (3) & (4) & (5) & (6) & (7) \\
\hline HURR & & & $\begin{array}{c}-0.159 * * \\
(0.004)\end{array}$ & $\begin{array}{c}0.059 \\
(0.044)\end{array}$ & $\begin{array}{c}-0.198^{* *} \\
(0.005)\end{array}$ & $\begin{array}{c}-0.158^{* *} \\
(0.005)\end{array}$ & $\begin{array}{c}-0.197^{* *} \\
(0.004)\end{array}$ \\
\hline HURR:-1 & & & & & & $\begin{array}{l}0.043^{* *} \\
(0.004)\end{array}$ & $\begin{array}{l}0.050 * * \\
(0.017)\end{array}$ \\
\hline HURR=2 & & & & & & $\begin{array}{l}-0.062 \\
(0.042)\end{array}$ & $\begin{array}{l}-0.060 \\
(0.042)\end{array}$ \\
\hline HURR $R_{t=3}$ & & & & & & $\begin{array}{c}0.055 \\
(0.046)\end{array}$ & $\begin{array}{c}0.054 \\
(0.046)\end{array}$ \\
\hline HURR -4 & & & & & & $\begin{array}{c}0.055 \\
(0.032)\end{array}$ & $\begin{array}{c}0.049 \\
(0.033)\end{array}$ \\
\hline HURRt-5 & & & & & & $\begin{array}{l}-0.017 \\
(0.018)\end{array}$ & $\begin{array}{l}-0.026 \\
(0.015)\end{array}$ \\
\hline $\log ($ INITIAL/ POP) & $\begin{array}{l}-0.151^{* *} \\
(0.004)\end{array}$ & $\begin{array}{l}-0.131^{* *} \\
(0.005)\end{array}$ & $\begin{array}{l}-0.132^{* *} \\
(0.005)\end{array}$ & $\begin{array}{l}-0.144^{* *} \\
(0.005)\end{array}$ & $\begin{array}{l}-0.132^{* *} \\
(0.005)\end{array}$ & $\begin{array}{l}-0.132^{* *} \\
(0.005)\end{array}$ & $\begin{array}{l}-0.132^{* *} \\
(0.005)\end{array}$ \\
\hline NGROWTH & & $\begin{array}{l}0.738^{* *} \\
(0.021)\end{array}$ & $\begin{array}{l}0.734^{* *} \\
(0.022)\end{array}$ & $\begin{array}{l}0.769 * * \\
(0.009)\end{array}$ & $\begin{array}{l}0.732 * * \\
(0.022)\end{array}$ & $\begin{array}{l}0.735^{* *} \\
(0.022)\end{array}$ & $\begin{array}{l}0.733^{* *} \\
(0.023)\end{array}$ \\
\hline \# Counties: & 409 & 409 & 409 & 528 & 409 & 409 & 409 \\
\hline Obs.: & 14724 & 14724 & 14724 & 19008 & 14724 & 14724 & 14724 \\
\hline HURR: & -- & --- & Tr.Pop.W. & Tr.Pop.W. & Un.W. & Tr.Pop.W. & Tr.Pop.W. \\
\hline Level: & County & County & County & County & County & County & County \\
\hline Period: & $\begin{array}{l}1970- \\
2005\end{array}$ & $\begin{array}{l}1970- \\
2005\end{array}$ & $\begin{array}{l}1970- \\
2005\end{array}$ & $\begin{array}{l}1970- \\
2005\end{array}$ & $\begin{array}{l}1970- \\
2005\end{array}$ & $\begin{array}{l}1970- \\
2005\end{array}$ & $\begin{array}{l}1970- \\
2005\end{array}$ \\
\hline GROWTH: & $\mathrm{PI}$ & PI & PI & PI & $\mathrm{PI}$ & $\mathrm{PI}$ & $\mathrm{PI}$ \\
\hline Method: & Kiviet & Kiviet & Kiviet & Kiviet & Kiviet & Kiviet & Kiviet \\
\hline
\end{tabular}

Notes: (1) ** and * are 1 and 5 per cent significance levels. (2) Bootstrapped standard errors in parentheses. (3) Kiviet: Kiviet's estimator; Pl: Personal Income; Tr.Pop.W: Tract level population weighted; Un.W.: Unweighted. (4) Time dummies included. 
Table 4: State and National Level Growth Regressions

\begin{tabular}{|c|c|c|c|c|c|c|c|}
\hline & (1) & (2) & (3) & (4) & (5) & (6) & (7) \\
\hline \multirow[t]{2}{*}{ HURRt } & $-3.998 * *$ & $-3.468 * *$ & $-0.095^{* *}$ & 0.003 & 0.002 & 0.002 & 0.003 \\
\hline & (0.331) & (1.018) & (0.008) & $(0.008)$ & $(0.006)$ & (0.006) & (0.009) \\
\hline \multirow[t]{2}{*}{ HURRt=1 } & $3.755^{* *}$ & $2.368^{*}$ & $-1.461^{* *}$ & 0.006 & -0.009 & -0.016 & -0.008 \\
\hline & $(0.163)$ & (1.004) & $(0.498)$ & $(0.031)$ & $(0.014)$ & $(0.016)$ & $(0.015)$ \\
\hline \multirow[t]{2}{*}{ HURRt=2 } & 0.230 & $0.412^{* *}$ & $1.476^{* *}$ & 0.014 & 0.001 & -0.017 & -0.008 \\
\hline & $(0.153)$ & (0.070) & $(0.450)$ & $(0.032)$ & $(0.012)$ & $(0.016)$ & $(0.014)$ \\
\hline \multirow[t]{2}{*}{ HURRt-3 } & 0.042 & 0.127 & $0.767^{* *}$ & 0.028 & 0.013 & -0.018 & -0.008 \\
\hline & $(0.024)$ & (0.539) & $(0.166)$ & $(0.033)$ & $(0.014)$ & $(0.020)$ & $(0.015)$ \\
\hline \multirow[t]{2}{*}{ HURRt } & 0.175 & 0.247 & -0.094 & 0.019 & 0.006 & -0.016 & -0.007 \\
\hline & $(0.244)$ & (1.633) & $(0.381)$ & (0.087) & $(0.012)$ & (0.017) & (0.013) \\
\hline \multirow[t]{2}{*}{ HURR $\mathbb{R}_{-5}$} & $0.507^{* *}$ & 0.394 & 0.078 & 0.048 & 0.004 & -0.007 & -0.012 \\
\hline & $(0.103)$ & (0.477) & $(0.139)$ & $(0.086)$ & $(0.018)$ & $(0.030)$ & $(0.023)$ \\
\hline \multirow[t]{2}{*}{ HURRt-6 } & 0.196 & 1.105 & 0.003 & 0.021 & 0.012 & -0.015 & -0.007 \\
\hline & $(0.184)$ & $(0.767)$ & (1.020) & $(0.102)$ & $(0.016)$ & (0.095) & $(0.019)$ \\
\hline \multirow[t]{2}{*}{ HURRt-7 } & 0.050 & 0.662 & 0.414 & 0.024 & -0.004 & -0.014 & 0.000 \\
\hline & $(0.461)$ & $(2.547)$ & $(0.234)$ & (0.082) & $(0.008)$ & (0.108) & $(0.016)$ \\
\hline $\log (\mathrm{INITIAL})$ & $\begin{array}{c}-0.273^{* *} \\
(0.022)\end{array}$ & $\begin{array}{c}-0.315^{* *} \\
(0.028)\end{array}$ & $\begin{array}{c}-0.095^{* *} \\
(0.008)\end{array}$ & $\begin{array}{c}-0.127^{* *} \\
(0.030)\end{array}$ & $\begin{array}{l}-0.026 \\
(0.024)\end{array}$ & $\begin{array}{l}-0.014 \\
(0.011)\end{array}$ & $\begin{array}{l}-0.056^{*} \\
(0.023)\end{array}$ \\
\hline NGROWTH & $\begin{array}{l}0.496^{* *} \\
(0.043)\end{array}$ & $\begin{array}{l}0.622 * * \\
(0.064)\end{array}$ & $\begin{array}{l}0.900^{* *} \\
(0.033)\end{array}$ & $\begin{array}{c}-0.046^{* *} \\
(0.005)\end{array}$ & --- & --- & --- \\
\hline Constant & -- & --- & --- & --- & $\begin{array}{c}0.283 \\
(0.246) \\
\end{array}$ & $\begin{array}{c}0.157 \\
(0.113) \\
\end{array}$ & $\begin{array}{l}0.194^{*} \\
(0.087) \\
\end{array}$ \\
\hline \# Sta tes: & 19 & 19 & 19 & ב--- & "--- & --- & --- \\
\hline Obs: & 2603 & 2603 & 4370 & 36 & 58 & 36 & 58 \\
\hline HURR: & Tr.Pop.W. & Ct.Pop.W. & Ct.Pop.W. & Ct.Pop.W. & Ct.Pop.W. & Ct.Pop.W. & Ct.Pop.W. \\
\hline Level: & State & State & State & National & National & National & National \\
\hline Period: & $\begin{array}{l}1970- \\
2005 \\
\end{array}$ & 1970-2005 & 1948-2005 & $1970-2005$ & 1948-2005 & 1970-2005 & 1948-2005 \\
\hline Frequency & quarterly & quarterly & quarterly & quarterly & quarterly & quarterly & quarterly \\
\hline Method: & Kiviet & Kiviet & Kiviet & OLS & OLS & OLS & OLS \\
\hline $\begin{array}{l}\text { Growth } \\
\text { Var. }\end{array}$ & $\mathrm{PI}$ & $\mathrm{PI}$ & $\mathrm{PI}$ & $\mathrm{PI}$ & $\mathrm{PI}$ & GDP & GDP \\
\hline
\end{tabular}

Notes: (1) ** and * are 1 and 5 per cent significance levels. (2) Bootstrapped standard errors in parentheses for Kiviet and normal standard errors for OLS. (3) Kiviet: Kiviet's estimator; PI: Personal Income; GDP: gross domestic product; Tr.Pop.W: Tract level population weighted; Ct.Pop.W: County level population weighted. (4) Time and quarter dummies included. 
Figure 1: Radar composite of Andrew making landfall August 24, 1992, at Dade County, Florida

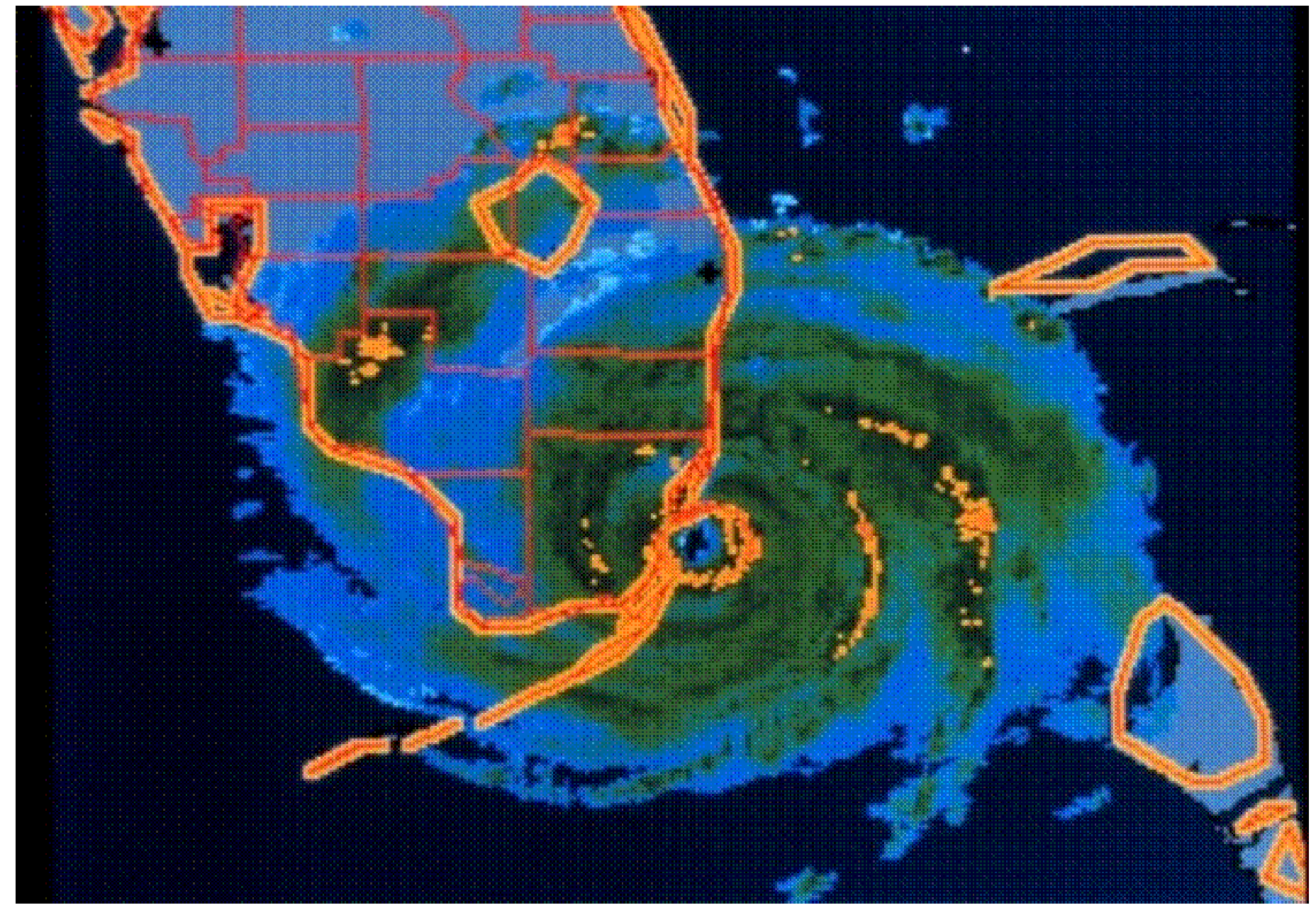

Source: NOAA at http://www.photolib.noad.gov/htmls/wea00522.htm 
Figure 2: Coastal Counties in the North Atlantic Basin Region

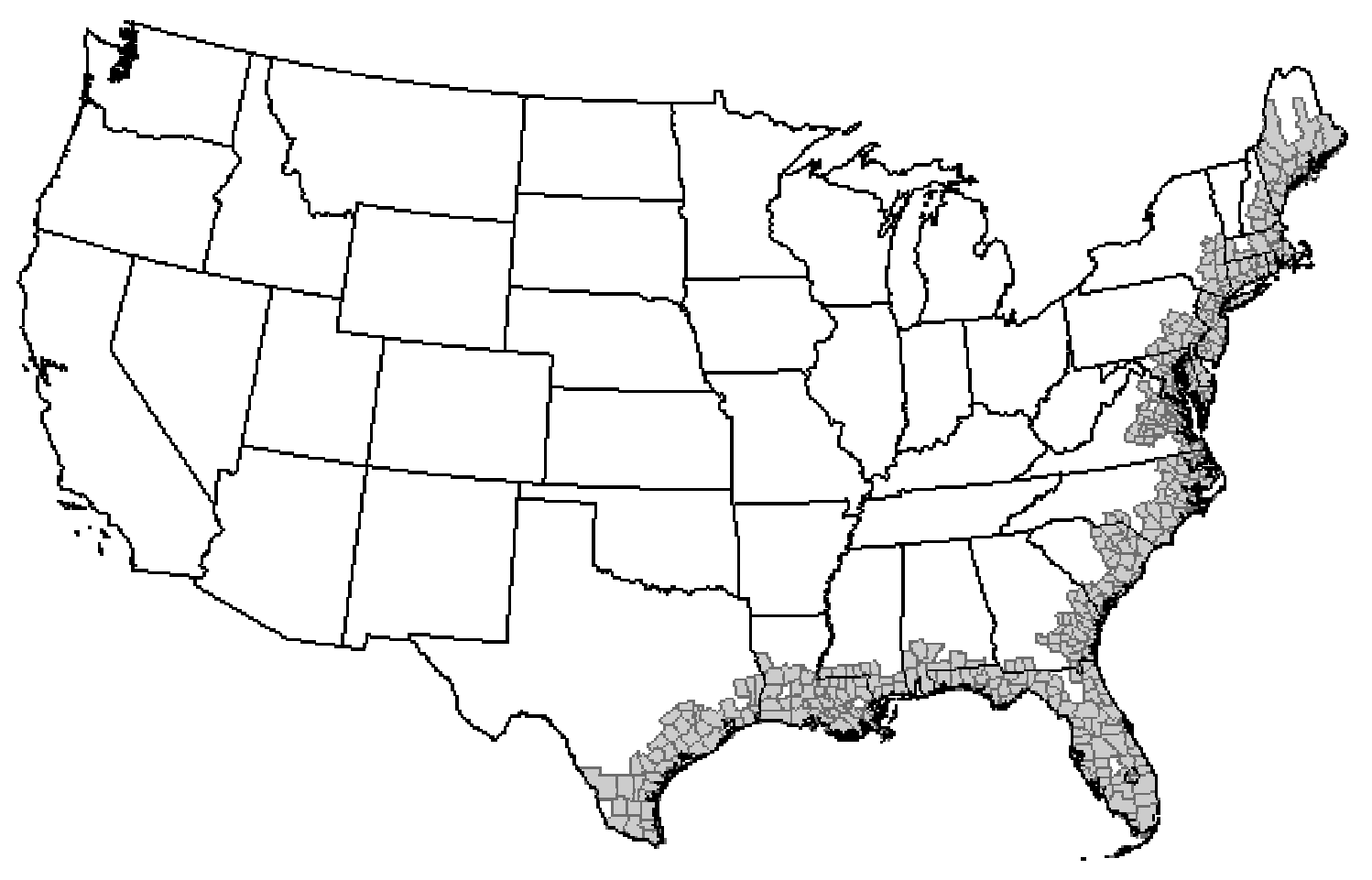


Figure 3: Tropical Storm Activity in the North Atlantic Basin Region since 1970

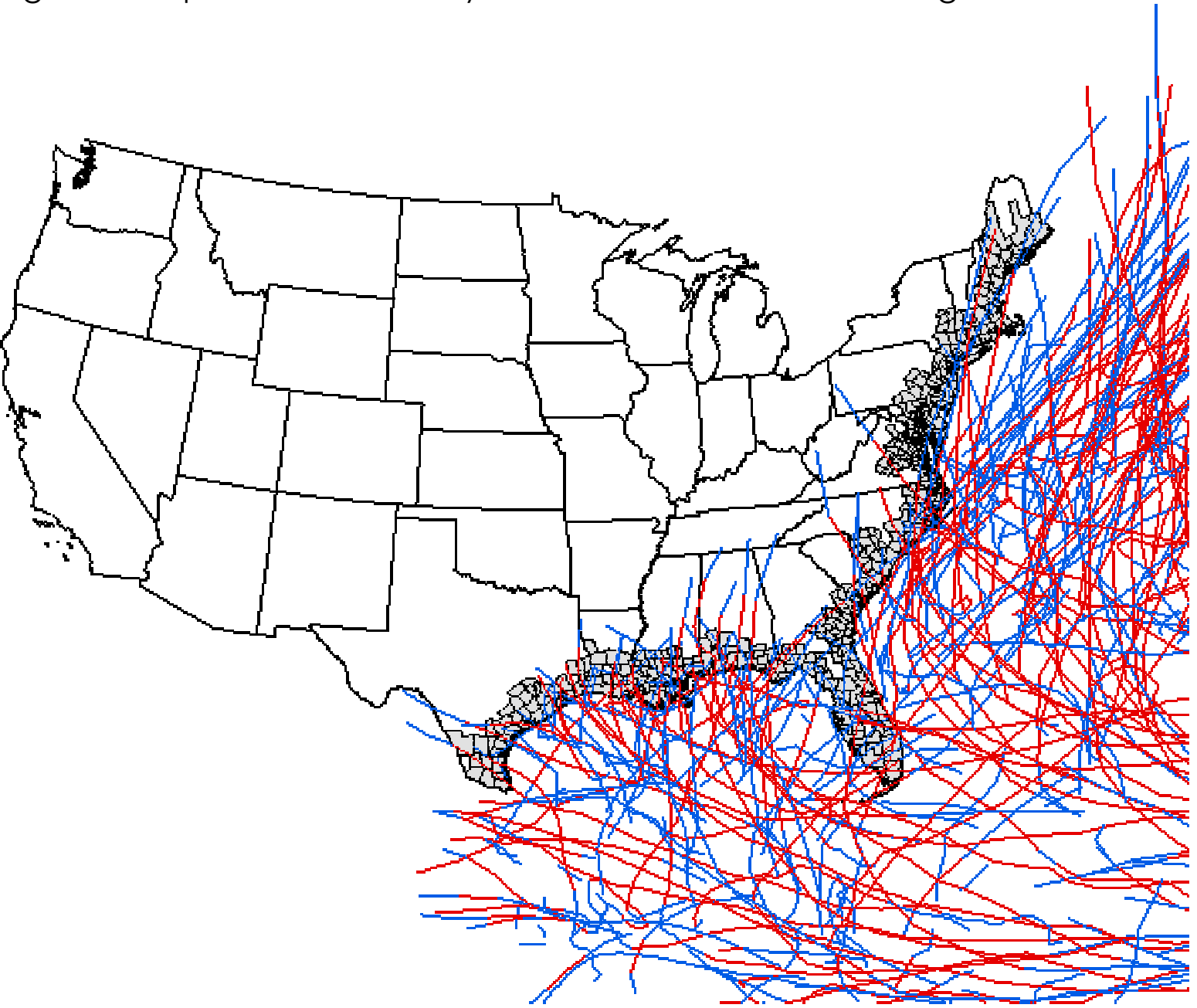


Figure 4: Relevant Hurricanes

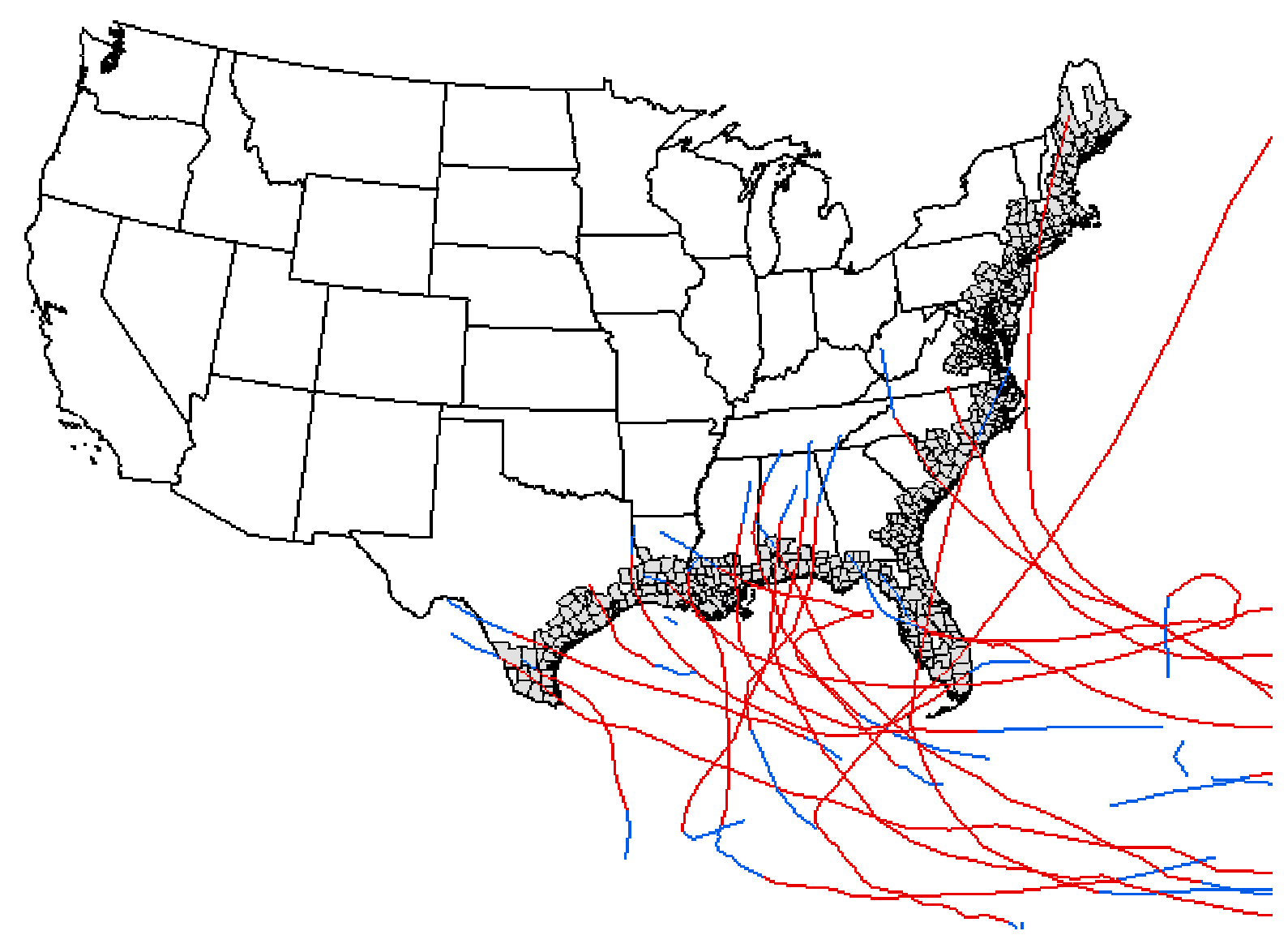


Figure 5: Hurricane Andrew Path

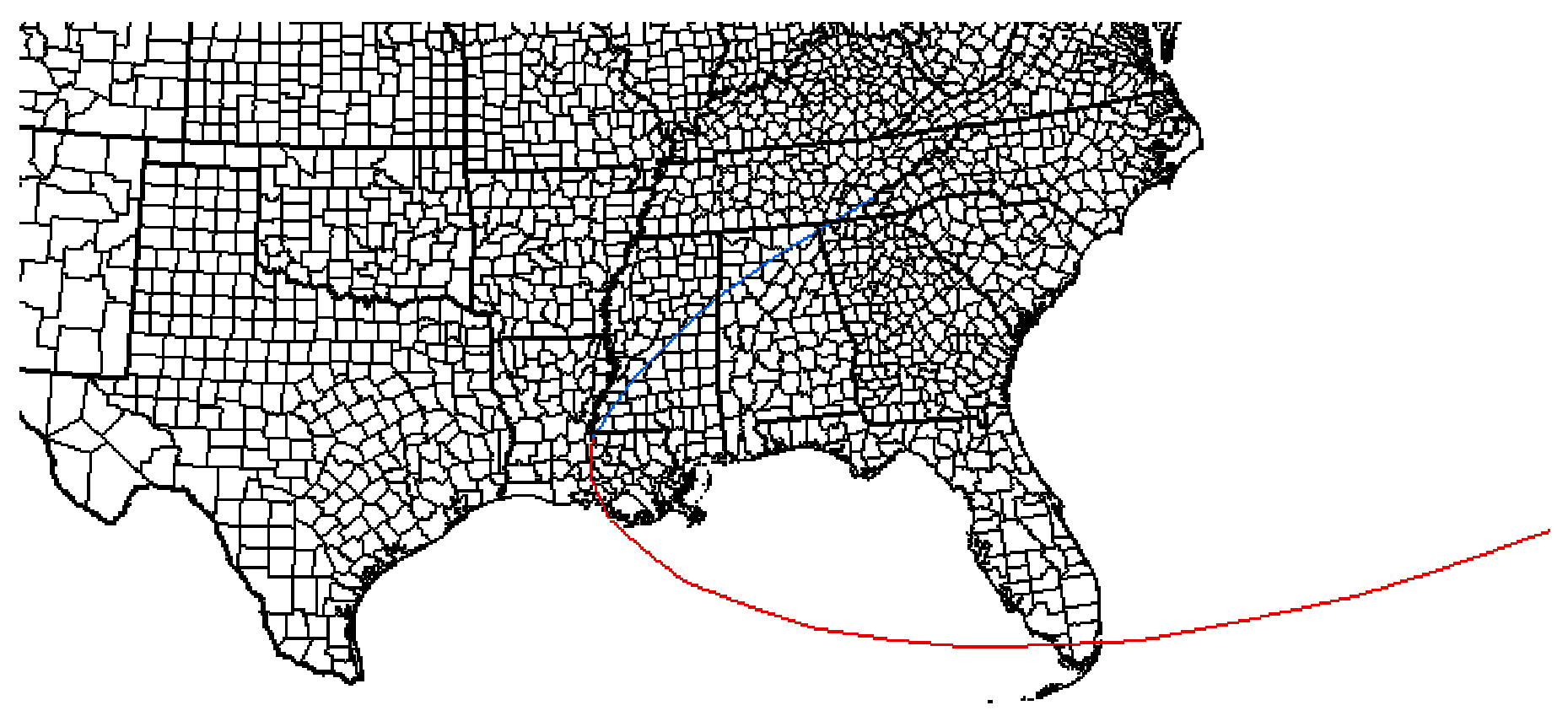


Figure 6: Hurricane Andrew Speed Distribution in Florida

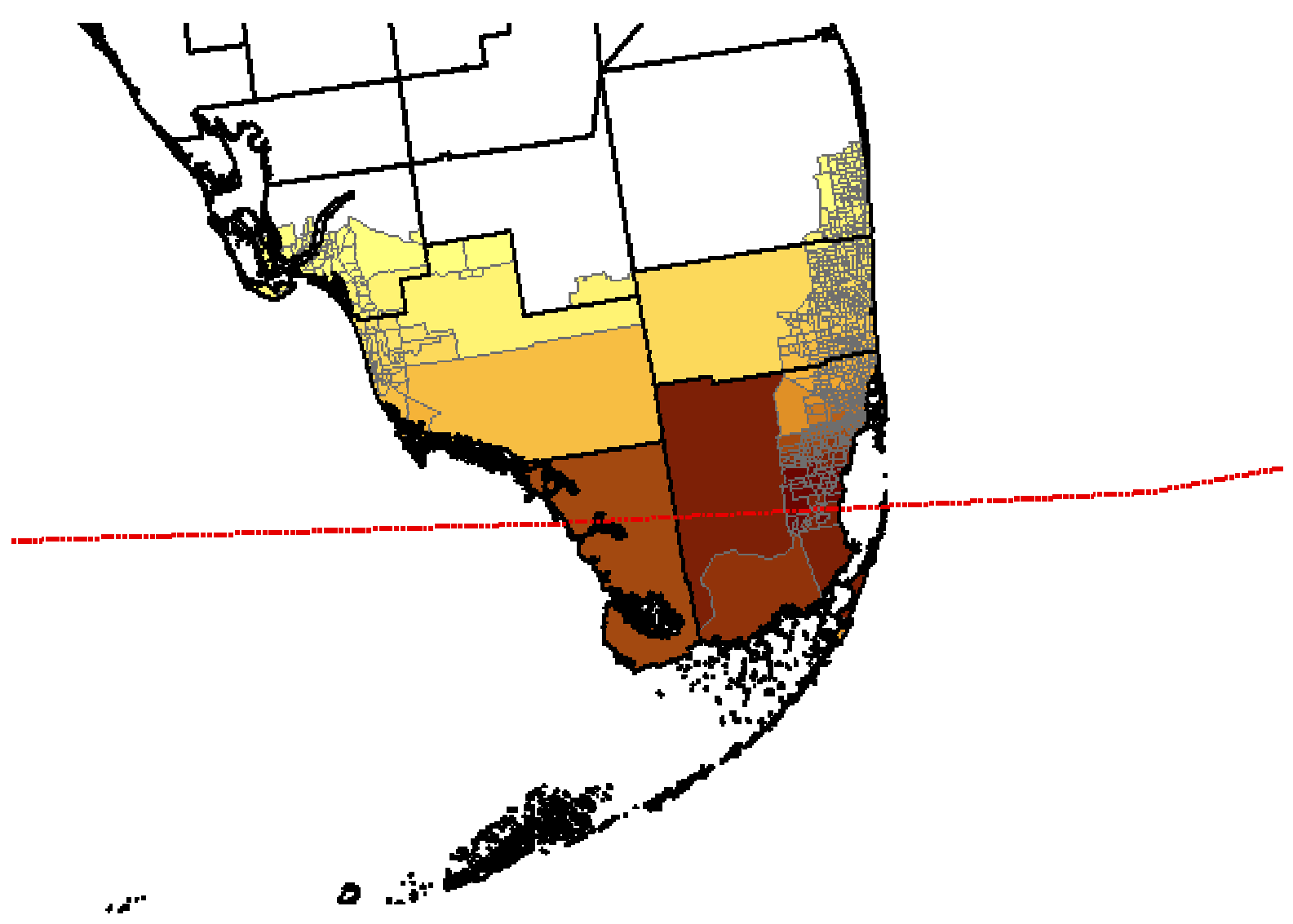


Figure 7: Hurricane Andrew Population Share (POP_SHARE) Distribution in Florida

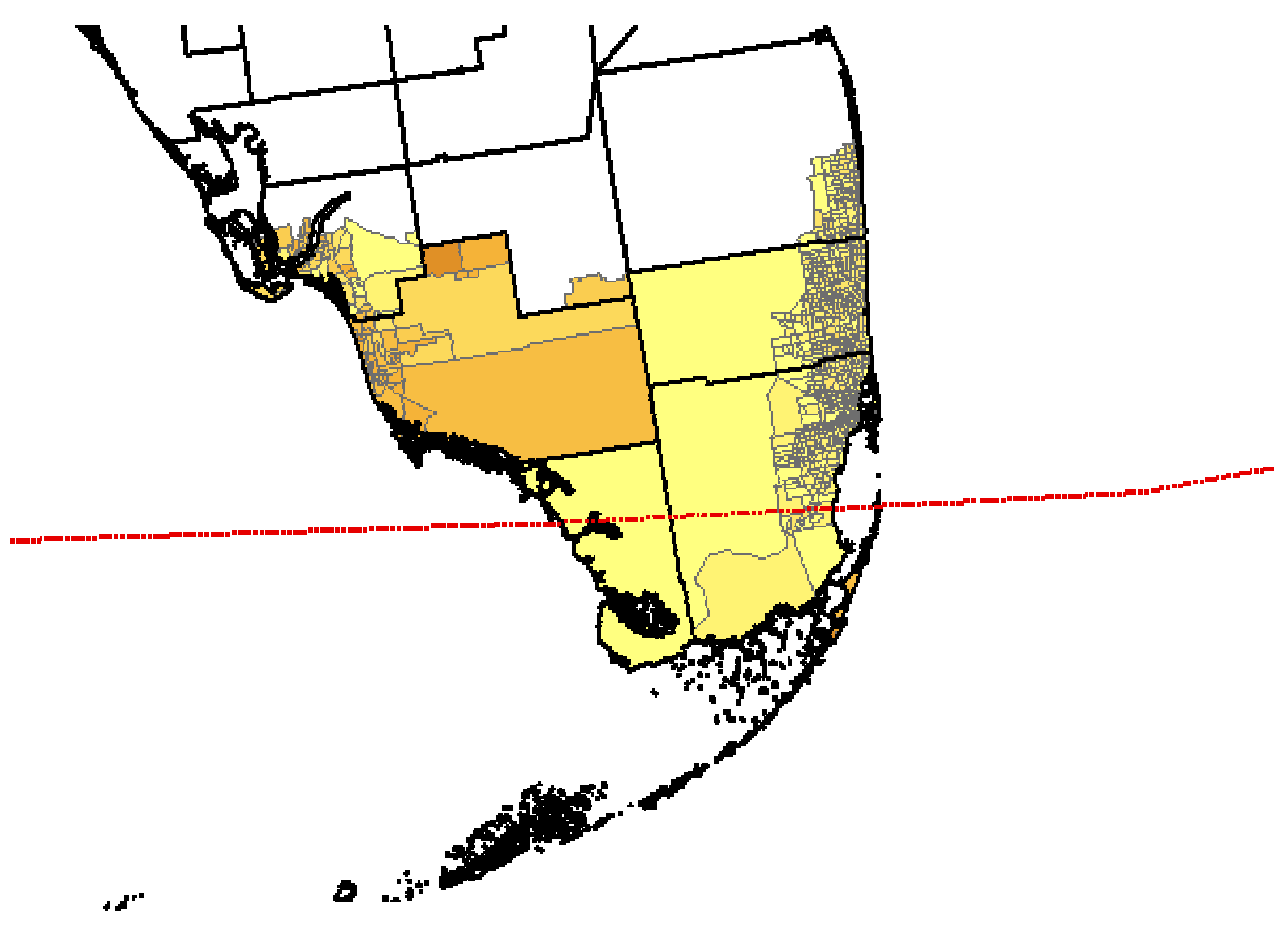


Figure 8: Hurricane Andrew Destruction

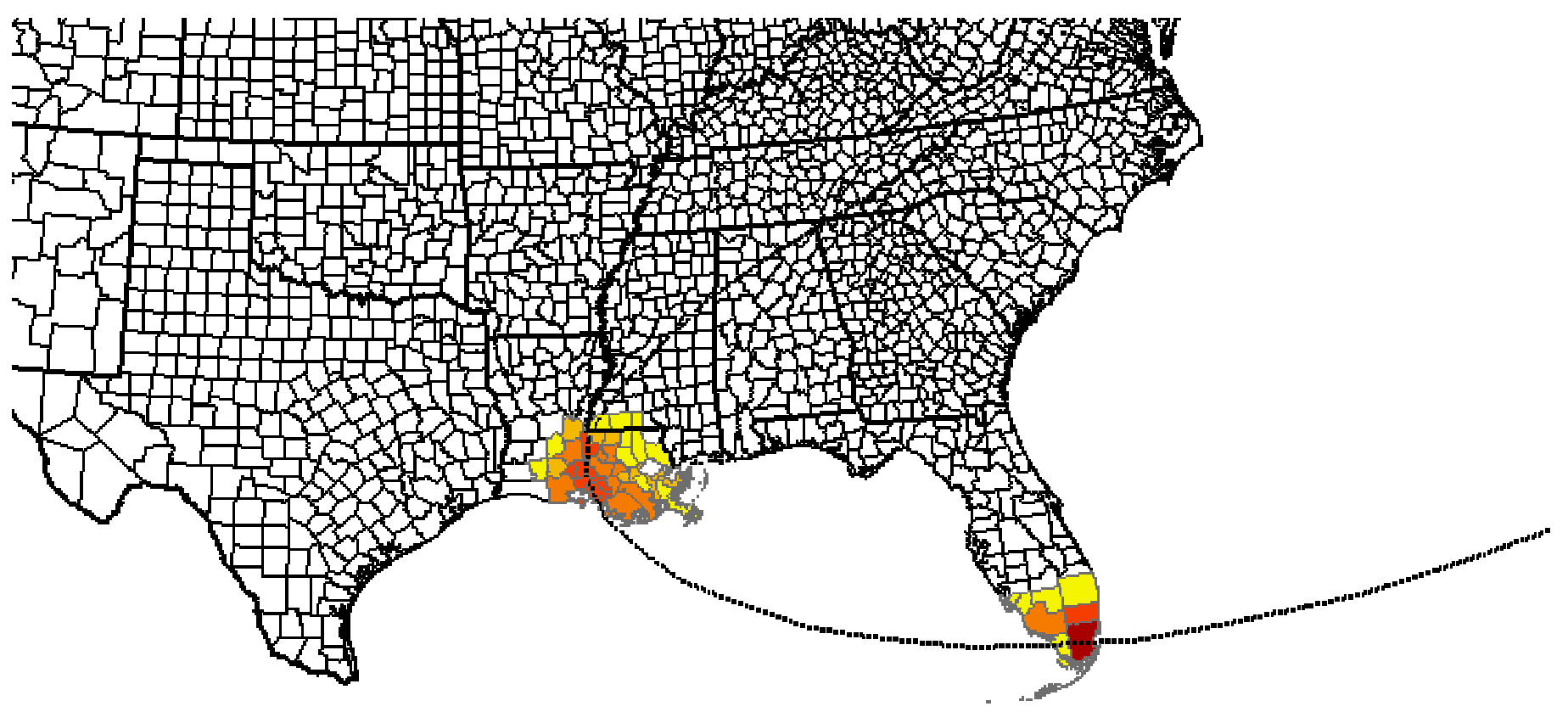


Figure 9: Mean Value of HURR over 1970-2005

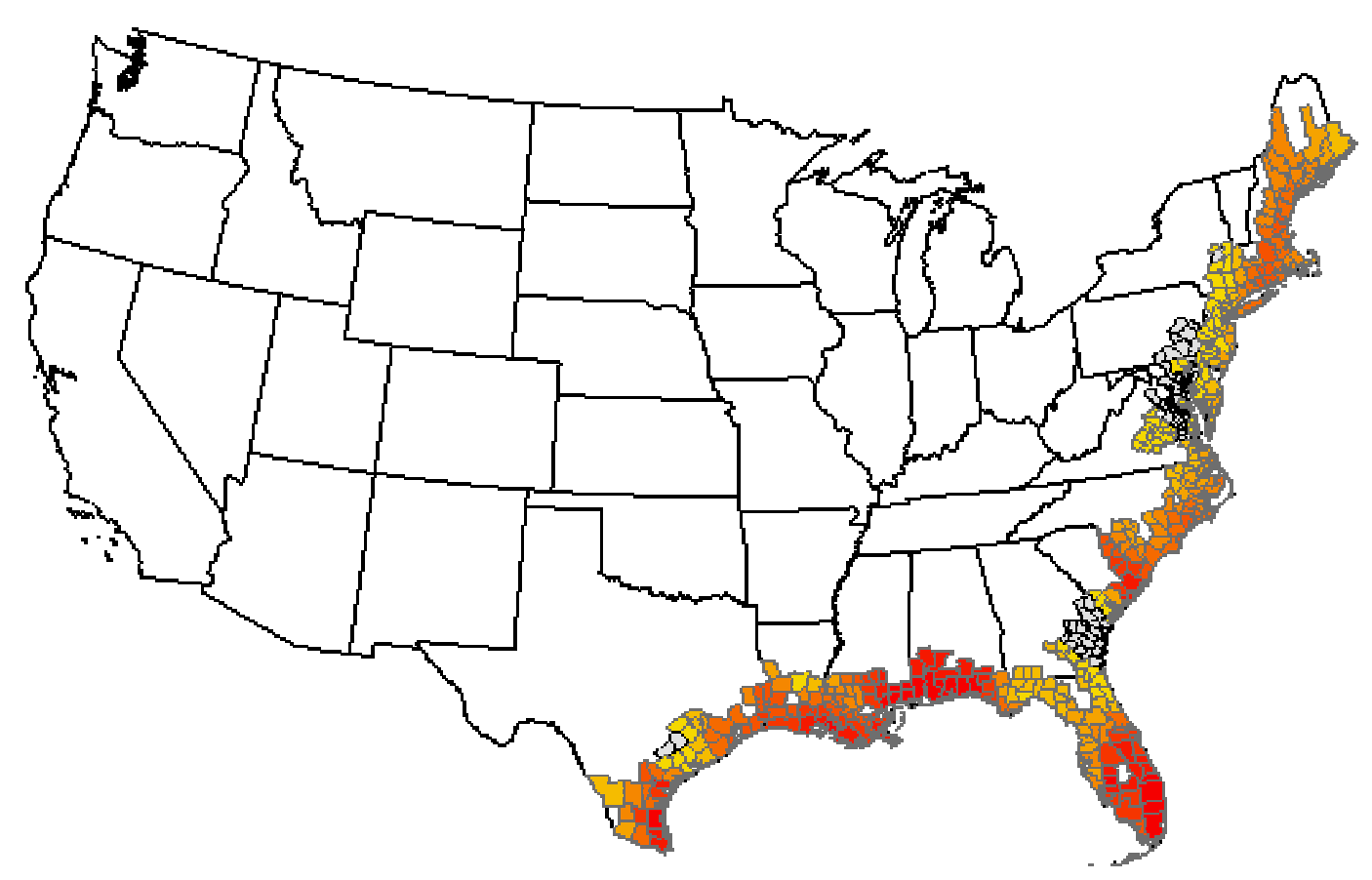

